\title{
Application of Knowledge Visualization in Senior High School Information Technology Classroom Teaching
}

\author{
Huansong YANG \\ Hangzhou Institute of Service Engineering \\ Hangzhou Normal University \\ Hangzhou, China
}

\author{
Yiming LIU * \\ Hangzhou Institute of Service Engineering \\ Hangzhou Normal University \\ Hangzhou, China \\ *1179870206@qq.com
}

\begin{abstract}
Knowledge visualization has become the development trend of the current era. Based on the "visual teaching", this work explored the visual teaching of senior high school information technology courses, conducting teaching design and practice based on knowledge visualization. This work studied and analyzed students' information literacy, achievement and classroom performance through a questionnaire survey, observation and statistical analysis, so as to provide some references for future teaching. The work found that knowledge visualization teaching has a significant effect on improving students' academic performance, students' enthusiasm of learning, and students' classroom participation. However, the information literacy of students is a process of continuous accumulation. Short-term teaching has a certain effect on the improvement of students' information literacy, but the effect is not obvious.
\end{abstract}

Keywords-visualization; teaching; information technology course; SPSS

\section{RESEARCH BACKGROUND AND SIGNIFICANCE}

New fields such as Internet Plus Education have become the development trend of current primary and secondary school teaching. The "Ordinary High School Information Technology Curriculum Standards" promulgated in 2017 defines the core literacy of the discipline as information awareness, computational thinking, digital learning and innovation, and information society responsibility, emphasizing the essence of project learning, reconstructing teaching methods, and creating a digital learning environment. Focusing on the core literacy of the discipline, building a sustainable learning resource with the "Internet Plus" thinking [1]. Traditional teaching strategies and teaching methods can no longer meet the needs of today. The teaching content, teaching organization and teaching evaluation and other aspects of information technology courses should be reconstructed accordingly.

In the CNKI, using "knowledge visualization" as the subject to query, and the number of related documents in the past 10 years was obtained, as shown in Fig.1. Through this figure, it can be found that research related to knowledge visualization has grown rapidly in recent years, and visual teaching has received more and more attention. In 2013, Li Mang and others pointed out in Visualization Teaching Design
Method and Application that visualization is not only for convey information in a concise way, but also for analyzing information more deeply, which is suitable for target analysis, learner analysis, content analysis, strategy selection and valuation analysis, etc.[2]. In 2019, Zhou Changlin used virtual chemistry experiment software as the basic tool to explore the specific method and teaching application value of the visual teaching design in the section of "Salt hydrolysis", which shows that the visual teaching design can balance the process and result of thinking visualization, and conducive to strengthen students' understanding of the subject [3]. In teaching activities, visual teaching not only helps the presentation and transmission of information, but also helps students understand and reconstruct knowledge; not only can transfer explicit knowledge but also can transfer tacit knowledge [4]. However, the current research on visual teaching mainly focuses on teaching design, teaching strategies and the application in specific teaching, there is no systematic knowledge visualization teaching system [5]. The study of knowledge visualization teaching can improve the existing teaching, select appropriate visualization tools according to the type of teaching content, carry out visual teaching design, discover the teaching methods and teaching organization forms used in visual teaching, in order to carry out meaningful learning and effective teaching[6].

2008-2018 Trend map of knowledge visualization literature

200

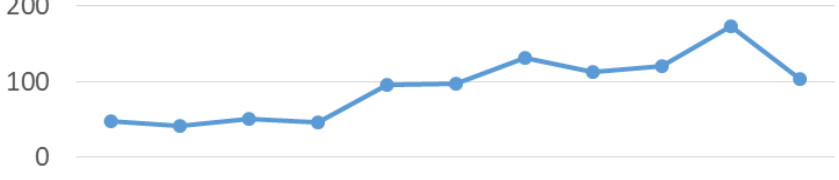

20082009201020112012201320142015201620172018

$\rightarrow$ literature number

Fig. 1. Trend map of knowledge visualization literature 


\section{RESEARCH METHODS AND TOOLS}

\section{A. Research Method}

\section{1) Questionnaire research}

Questionnaire research refers to the method of collecting respondents to collect data by making detailed and detailed questionnaires. Through questionnaire research, the information literacy and achievement information of students are collected before the start of teaching to reduce the influence of irrelevant variables and ensure the accuracy of the research. At the end of the teaching, the two pieces of information of the students have collected again, and compared with the data collected before the teaching, so as to draw the conclusion of the experiment. The Student Information Literacy Questionnaire in this study is based on the core literacy specified in the "Ordinary High School Information Technology Curriculum Standards” promulgated in 2017. Five questions are set in the order of information awareness, computational thinking, digital learning and innovation, and information social responsibility. Partially set 5 questions, among them, 6-10, 16 and 19 had a total score of 3 points, and the remaining scores were 5 points. The total score of the questionnaire was 86 points. SPSS software will be used to analyze the questionnaire data.

\section{2) Observation method}

Observation method refers to a method in which researchers use their own senses and auxiliary tools to directly observe the object to get some information according to a certain research purpose, research outline or observation table. Through observation, this study observes the students' class situation and analyzes the influence of visual teaching on students' classroom enthusiasm and participation.

\section{3) Statistical analysis}

Statistical analysis refers to a research method that through the analysis and research of the quantitative relationship between the scale, speed, scope and degree of the research object, and the mutual understanding, change rules and development trend of things, so as to achieve a correct interpretation and prediction of things. This study analyzes the data collected from the questionnaire survey to study the impact of visual teaching on students' information literacy, student achievement, and classroom situation.

\section{B. Research Tools}

\section{1) SPSS}

SPSS was originally called" Solutions Statistical Package for the Social Sciences". It is the general term of a series of software products and related services launched by IBM for statistical analysis and calculation, data mining, predictive analysis and decision support tasks, including Windows and Mac OS X. In 2000, with the expansion of product services and service, it was changed to "Statistical Product and Service Solution" in 2000. The SPSS features: using menus and dialogs, the vast majority of operations can be completed by mouse click; It has flexible variable transformation and file exchange system, the rich output of statistical charts, and compatible with Microsoft Offices software [7]. The software provides tools that enable users to view data quickly, formulate assumptions for other tests, perform processes that clarify relationships between variables, create clusters, discover trends, and make predictions.

\section{2) Mind Mapping}

In the early 1960s, Tony Burzan created the mind map inspired by the extension of the neuron, which is mainly used to express divergent thinking. Each type of data that enters the brain can become a thinking center, and thus radiate out the nodes. Each node represents a link to the central theme, and each link can become another central theme and then radiate out the nodes, showing a radioactive stereoscopic structure [8].

\section{RESEARCH PROCESS}

\section{A. Subjects}

The subjects of this experiment were the students of the experimental class and the control class of a senior high school in Hangzhou with similar grades and similar students in all aspects. What's more, the number of experimental classes was 40 and the number of control classes was 41.

As can be seen from Fig. 2, the overall performance of the two classes is similar, and the students are generally consistent, in order to reduce the impact of irrelevant variables.

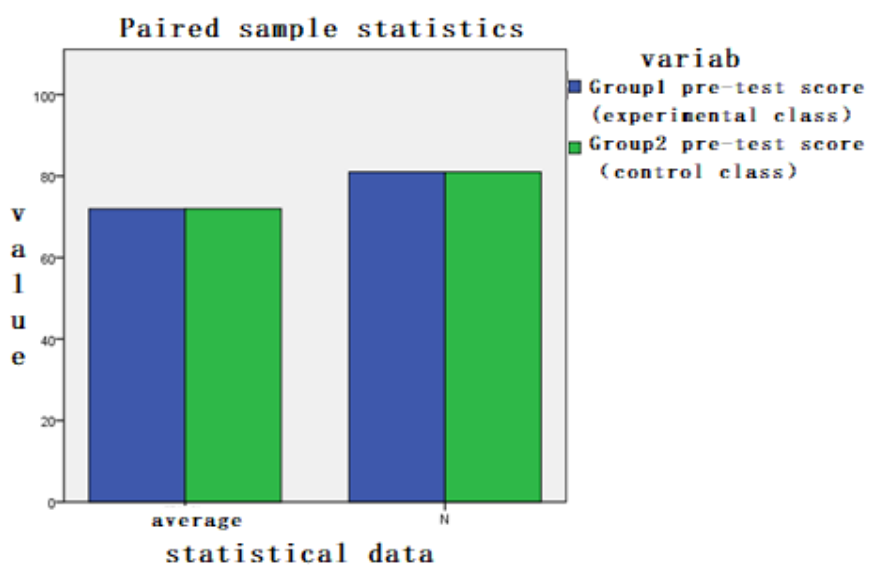

Fig. 2. Analysis of the results of the two classes before the experiment.

\section{B. Experimental Preparation}

\section{1) Teaching content}

The content of this research is the second chapter of "Information Technology Foundation" published by Zhejiang Education Publishing House.

2) Survey material

Student information literacy questionnaire; "Source and Access of Information” test volume.

3) Teaching environment

Multimedia computer; Polar domain electronic control system.

\section{Experimental procedure}

- Before the experiment, two classes of students were arranged to complete the information literacy 
questionnaire to collect information literacy about students. The data was analyzed by SPSS software to ensure that the information level of the two classes of students was equal, and guaranteed the reliability and validity of the experimental results.

TABLE I. RELIABILITY STATISTICS

\begin{tabular}{|l|l|}
\hline Cronbach`s alpha & Item`s number \\
\hline .786 & 20 \\
\hline
\end{tabular}

According to TABLE I, the reliability of Student Information Literacy Questionnaire is greater than 0.75, which is good enough to be investigated.

- In the experiment, students of two classes were taught by experimental teaching method.

- The students in the experimental class adopted the task-driven approach, with the goal of "draw up the May 1st Shanghai travel plan”, discussing in groups, using the mind map to write out the necessities that each group thinks should be prepared, and referring network information to formulate detailed travel strategies; The control group was taught by traditional way according to the knowledge points.

- After the experiment, the students of two classes filled in the Information Literacy Questionnaire again, completed the "Source and Acquisition of Information" test volume, and used SPSS to analyze the collected data, and analyzed the influence of visual teaching on students' information literacy, students' grades and students' performance according to the results.

\section{Experimental summary}

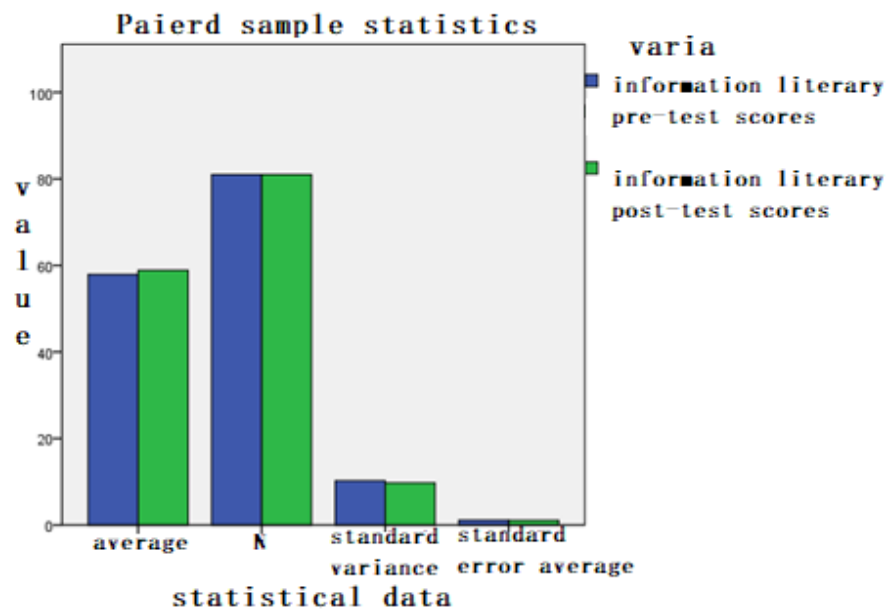

Fig. 3. Information literacy of two classes before and after the experiment
TABLE II. PAIRED SAMPLE STATISTICS

\begin{tabular}{|c|l|l|l|l|l|}
\hline \multicolumn{2}{|c|}{} & Average & N & $\begin{array}{c}\text { Standard } \\
\text { variance }\end{array}$ & $\begin{array}{c}\text { Standard } \\
\text { error } \\
\text { average }\end{array}$ \\
\hline \multirow{4}{*}{ Group 1 } & $\begin{array}{l}\text { Pre-test } \\
\text { score(E) }\end{array}$ & 71.94 & 81 & 9.498 & 1.055 \\
\cline { 2 - 6 } & $\begin{array}{l}\text { Pre-test } \\
\text { score(C) }\end{array}$ & 71.98 & 81 & 7.632 & .848 \\
\hline \multirow{4}{*}{ Group 2 } & $\begin{array}{l}\text { Post-test } \\
\text { score(E) }\end{array}$ & 74.56 & 81 & 8.526 & .947 \\
\cline { 2 - 6 } & $\begin{array}{l}\text { Post-test } \\
\text { score(C) }\end{array}$ & 71.85 & 81 & 7.296 & .811 \\
\hline \multirow{3}{*}{ Group 3 } & $\begin{array}{l}\text { Pre-test } \\
\text { score(E) }\end{array}$ & 71.94 & 81 & 9.498 & 1.055 \\
\cline { 2 - 6 } & $\begin{array}{l}\text { Post-test } \\
\text { score(E) }\end{array}$ & 74.56 & 81 & 8.526 & .947 \\
\hline & $\begin{array}{l}\text { Pre-test } \\
\text { score(C) }\end{array}$ & 71.98 & 81 & 7.632 & .848 \\
\cline { 2 - 6 } & $\begin{array}{l}\text { Post-test } \\
\text { score(C) }\end{array}$ & 71.85 & 81 & 7.296 & .811 \\
\hline
\end{tabular}

TABLE III. DISTRIBUTION OF THE NUMBER OF PEOPLE IN EACH CLASS BEFORE AND AFTER THE EXPERIMENT

\begin{tabular}{|l|l|l|l|l|l|}
\hline & $\begin{array}{c}\text { Under } \\
\mathbf{6 0}\end{array}$ & $\mathbf{6 0}$ to $\mathbf{7 0}$ & $\mathbf{7 0}$ to 80 & $\mathbf{8 0}$ to 90 & Over 90 \\
\hline Pre-test(E) & 4 & 27 & 27 & 21 & 2 \\
\hline $\begin{array}{l}\text { Post- } \\
\text { test(E) }\end{array}$ & 2 & 21 & 24 & 27 & 7 \\
\hline Pre-test(C) & 5 & 24 & 37 & 13 & 2 \\
\hline $\begin{array}{l}\text { Post- } \\
\text { test(C) }\end{array}$ & 4 & 25 & 38 & 13 & 1 \\
\hline
\end{tabular}

The following conclusions can be drawn from the above experiments :

- $\quad$ Fig. 3 shows the score analysis of the two classes of information literacy questionnaires after teaching. It is not difficult to find that the information literacy of the two classes is higher than it before teaching, but the fluctuation is not large. Students' information literacy is accumulated in daily life and learning, and cannot be suddenly improved through the teaching of short time teaching.

- As can be seen from TABLE II, after the experiment, the average score of the experimental class was 71.94 liters to 74.56, and the overall increase was 2.62 points. What's more, there was no significant difference in the control class. At the same time, the standard deviation of the experimental class was 9.498. It dropped to 8.526 and the overall decrease was 0.972 . According to TABLE III, it is not difficult to find that after the teaching of the experimental class, the overall score of the students has improved, and the number of failing students has decreased. The number of people above 90 points increased from 2 to 7, the control class did not have a big difference, and visual teaching effect is obvious.

- In the actual teaching process, the author found that compared with the control class, students in the experimental class have a significantly higher interest in learning. Students are full of expectations for information technology courses, high-class 
participation and homework completion, and more enthusiasm for learning.

\section{SUMMARY}

Visual teaching is to express some knowledge through the form of images, etc., to help learners to obtain explicit and tacit knowledge as soon as possible. Through the above research, it can be found that visual teaching can mobilize the enthusiasm and participation of students to a greater extent, and it is of great help to improve students' information literacy and academic achievement. At the same time, according to the task of "draw up the May 1st Shanghai travel plan" in this chapter, the teaching is carried out, starting from the actual situation of the students, not only completed the course objectives, but also made the students learning about Shanghai, Infiltrating the ideological and political education while making budget adjustments, and cultivating students' ability to use the knowledge they have learned to solve practical problems.

However, due to the limitations of objective conditions, this study is only focused on two classes, the data collected is not sufficient, and the analysis of visual teaching still needs to be improved. In addition, visual teaching requires teachers to master higher visual teaching skills, which also puts forward higher requirements. In the future study and research, there is still has a large space for development in visual teaching.

\section{REFERENCES}

[1] Ministry of Education of the People's Republic of China, Ordinary High School Information Technology Curriculum Standards, Beijing: People's Education Press, 2017. (In Chinese)

[2] Li Mang, "Visual teaching design method and application" vol. 3. Eeducation Research, 2013, pp.16-22. (In Chinese)

[3] Zhou Changlin, "Visual teaching design based on IrYdium chemistry lab--taking 'Hydrolysis of Salts' as an example”, Chinese Journal of Chemical Education, 2019, pp.75-79. (In Chinese)

[4] Tan Zhanglu, Fan Yifang, Lv Ming, Zhang Changlu, "Theoretical development of information visualization and construction of framework system, ” Information studies: Theory \& Application, 2013,pp.16-19. (In Chinese)

[5] Weng Zhilin, "Design and application of information technology visualization teaching in junior middle school," Shandong Normal University, 2018. (In Chinese)

[6] An Qianru, "Research and application of information technology visualization teaching in senior one,” Tianjin Normal University, 2014. (In Chinese)

[7] Reng Yanling, Zhu Mingfang, "Student test paper analysis method based on statistical software SPSS," Journal of Chongqing Institute of Technology, 2007, pp.95-98. (In Chinese)

[8] Hao Jialing, "Application of visualization teaching in physics review of junior middle school,” Inner Mongolia Normal University, 2018. (In Chinese) 